\title{
Udostępnianie utworów na licencjach Creative Commons - wybrane aspekty
}

Celem artykułu jest usystematyzowanie najważniejszych zasad dotyczących wzorców licencji udostępnianych przez organizację Creative Commons (tzw. licencji CC), w tym struktury i charakteru tych licencji. Zakresem analizy objęto także niektóre kwestie związane z możliwością wykorzystywania wzorców licencji Creative Commons jako alternatywy dla tradycyjnego modelu ochrony prawnoautorskiej utworów oraz sygnalizacyjnie odniesiono się do zastrzeżeń związanych z ich stosowaniem na gruncie polskiego prawa. Ostatnia część tekstu odnosi się do sposobu udzielania licencji Creative Commons.

Słowa kluczowe: Creative Commons, licencja, prawo autorskie

Making a work available under Creative Commons licenses - selected aspects: The purpose of the article is to systematize the most important information regarding Creative Commons licenses, released by the Creative Commons organization, including the structure and nature of these licenses. The scope of the analysis also covered some issues related to the possibility of using the Creative Commons licenses as an alternative to the traditional model of copyright protection. The article also describes some expressed reservations about using Creative Commons licenses under Polish law. The last part of the text refers to the method of granting the Creative Commons licenses.

Keywords: Creative Commons, license, copyright

Ekspert ds. legislacji BAS • agnieszka.tomaszewska@sejm.gov.pl •

https://orcid.org/0000-0001-9524-8671

\section{Wstęp}

System licencji Creative Commons (licencje CC) powstał w wyniku działań amerykańskiej, pozarządowej organizacji Creative Commons oferującej darmowe rozwiązania oraz narzędzia, służące do zarządzania prawami autorskimi. Głównym celem twórców udostępnianych wzorców było stworzenie kompromisu między pełną ochroną praw autorskich a jak najszerszym dzieleniem się powstałą twórczością. Stworzony przez organizację Creative Commons model jest postrzegany jako alternatywa dla tradycyjnego obrotu prawami autorskimi i pokrewnymi ${ }^{1}$. Licencje te pozwalają zastąpić model „wszystkie prawa zastrzeżo-

1 W. Machała, Wybrane cywilnoprawne aspekty licencji „creative commons”, „Monitor Prawniczy” 2009, nr 8, s. 422. 
ne” regułą „pewne prawa zastrzeżone” - przy jednoczesnym poszanowaniu zasad tradycyjnego prawa autorskiego ${ }^{2}$.

Największą zaletą stworzonego systemu jest ich międzynarodowy charakter zostały przetłumaczone na wiele języków, a symbol i znaczenie licencji CC są zrozumiałe dla twórców i użytkowników na całym świecie. Polski oddział Creative Commons Polska funkcjonuje od 2005 r. $^{3}$.

\section{Struktura i rodzaje licencji Creative Commons}

Udostępniane przez organizację Creative Commons wzorce powstały na bazie ogólnych postanowień licencyjnych. Budowane są poprzez dodawanie odpowiednich „elementów” (nazywanych także: warunkami, klauzulami, atrybutami). Warunek jest utożsamiany $\mathrm{z}$ nałożeniem określonego obowiązku na licencjobiorcę . Wspólną bazą licencji CC jest zezwolenie na szerokie wykorzystywanie utworu oryginalnego oraz opracowań utworów i przedmiotów praw pokrewnych stanowiących przedmiot licencji ${ }^{5}$. Cztery atrybuty wykorzystywane w licencjach $\mathrm{CC}$ to $^{6}$ :

- BY (Attribution, Uznanie autorstwa) - postanowienie „podstawowe”, umożliwiające kopiowanie, rozpowszechnianie, przedstawianie i wykonywanie objętego prawem autorskim utworu oraz opracowywanie na jego podstawie utworów zależnych, pod warunkiem uznania autorstwa. Klauzula ta wymaga podania informacji o autorstwie, źródle oraz licencji. Wprowadza zatem obowiązki podobne do wynikających z polskich przepisów o osobistych prawach autorskich ${ }^{7}$.

2 Https://creativecommons.pl/poznaj-licencje-creative-commons/ [dostęp 19 września 2019 r.].

3 Https://creativecommons.pl/o-nas/ [dostęp 19 września 2019 r.].

4 D. Klimas, A. Zwolińska [w:] Sporządzanie umów elektronicznych. Komentarz praktyczny, wzory umów, orzecznictwo, red. J. Gołaczyński, 2017, Legalis.

5 K. Siewicz, Otwarty dostęp do publikacji naukowych. Kwestie prawne, 2012, s. 17, http://otworzksiazke.pl/ksiazka/otwarty_dostep/, publikacja udostępniana na licencji Creative Commons Uznanie autorstwa 3.0 Polska, https://creativecommons.org/ licenses/by/3.0/pl/legalcode [dostęp 19 września 2019 r.].

6 Https://creativecommons.pl/poznaj-licencje-creative-commons/; zob. także: J. Hofmokl i in., Przewodnik po otwartej nauce, 2009, s. 78, https://otwartanauka.pl/images/PDFs/ zprzewodnik-po-otwartej-nauce.pdf, publikacja udostępniana na licencji Creative Commons Uznanie autorstwa 3.0 Polska, https://creativecommons.org/licenses/by/3.0/ pl/legalcode [dostęp 19 września 2019 r.].

7 K. Siewicz, Prawo autorskie $i$ wolne licencje, Koalicja Otwartej Edukacji, 2010, s. 8, http://koed.org.pl/wp-content/uploads/2014/09/siewicz-prawo-autorskie-i-wolne-licencje.pdf, publikacja udostępniana na licencji Creative Commons Uznanie au- 
- SA (Share-alike, Na tych samych warunkach) - zgodnie z tym atrybutem wolno rozpowszechniać opracowania utworów, ale tylko na licencji identycznej jak ta, na jakiej udostępniono utwór oryginalny (odpowiednik klauzuli copyleft w licencjach wolnego oprogramowania).

- NC (Non-comercial, Użycie niekomercyjne) - klauzula ta ogranicza uprawnienia licencjobiorcy do korzystania z utworu i opracowań wyłącznie w celu niekomercyjnym. Licencje bez tego warunku pozwalają korzystać $\mathrm{z}$ utworu praktycznie w każdym celu - z poszanowaniem praw osobistych.

- ND (No derivatives, Bez utworów zależnych) - warunek ten oznacza wymóg zachowania utworu w oryginalnej postaci.

Poszczególne licencje CC są kombinacjami wymienionych warunków. Zastosowanie jedynie warunku BY (Uznanie autorstwa) charakteryzuje pierwszą, najbardziej liberalną licencję CC. Dodatkowe elementy ograniczają dowolne korzystanie. Kombinacje czterech atrybutów tworzą sześć wzorców, różniących się od siebie zakresem ograniczeń praw autorskich, w zależności od wybranych elementów ${ }^{8}$.

- CC-BY (Uznanie autorstwa). Licencja ta pozwala na rozpowszechnianie, kopiowanie, zmienianie i tworzenie przy wykorzystaniu licencjonowanego utworu, także do celów komercyjnych. Jest to jedyna licencja, która zawiera tylko jeden warunek - oznaczenie autorstwa, źródła oraz licencji. Tym samym licencja CC-BY to najbardziej liberalna z licencji CC, która pozwala użytkownikowi na największy zakres działań (w tym także wszelkie tłumaczenia, przeróbki, adaptacje). Oznacza to w zasadzie pełną swobodę wykorzystania utworu, także w celach komercyjnych. Wybór licencji CC-BY pozwala odbiorcy na zmianę licencji, a także objęcie utworów zależnych pełną ochroną prawnoautorską. Takiej licencji używa m.in. strona Białego Domu, Bank Światowy, Fundacja Orange, Ministerstwo Spraw Zagranicznych, Ministerstwo Cyfryzacji oraz Ministerstwo Przedsiębiorczości i Technologii.

- CC-BY-SA (Uznanie autorstwa - Na tych samych warunkach). Zgodnie z postanowieniami tej licencji dozwolone jest rozpowszechnianie, kopiowanie, zmienianie, również w celach komercyjnych, przy jednoczesnym nałożeniu na licencjobiorcę dwóch obowiązków. Po pierwsze, wymagane jest oznaczenie autorstwa utworu, źródła i licencji. Po drugie, licencjobiorca jest zobowiązany udzielić takiej samej licencji na wszelkie utwory zależne, pochodzące od utworu będącego przedmiotem uprawnienia licencyjnego, których będzie autorem lub współautorem. Jest wykorzystywana m.in. w takich projektach jak Wikipedia.

torstwa - Na tych samych warunkach 3.0 Unported, https://creativecommons.org/ licenses/by-sa/3.0/deed.pl [dostęp 19 września 2019 r.].

8 Https://creativecommons.org/licenses/ [dostęp 19 września 2019 r.]. 
- CC-BY-NC (Uznanie autorstwa - Użycie niekomercyjne). Licencja ta pozwala na kopiowanie, wprowadzanie zmian, rozpowszechnianie, przedstawianie i wykonywanie utworu, będącego przedmiotem umowy licencji, jedynie w celach niekomercyjnych. Warunek ten nie obejmuje jednak utworów zależnych - mogą zostać objęte inną licencją.

- CC-BY-ND (Uznanie autorstwa - Bez utworów zależnych). Ten rodzaj licencji zezwala licencjobiorcy rozpowszechniać, kopiować, przedstawiać i wykonywać utwór (w jego oryginalnej postaci), również w celach komercyjnych, pod warunkiem nierozpowszechniania utworów zależnych. Przetwarzając lub tworząc na podstawie utworu, nie wolno rozpowszechniać zmodyfikowanych treści.

- CC-BY-NC-SA (Uznanie autorstwa - Użycie niekomercyjne - Na tych samych warunkach). Postanowienia tej licencji uprawniają do rozpowszechniania, przedstawiania i wykonywania utworu przez licencjobiorcę, ale jedynie do celów niekomercyjnych. Nakładają także na licencjobiorców obowiązek zastosowania tych samych postanowień licencyjnych do utworów zależnych powstałych przez odpowiednie użycie utworu, który jest przedmiotem uprawnienia licencyjnego.

- CC-BY-NC-ND (Uznanie autorstwa - Użycie niekomercyjne - Bez utworów zależnych). Na podstawie tej licencji możliwe jest rozpowszechnianie, przedstawianie i wykonywanie utworu jedynie dla celów niekomercyjnych. Kolejnym obowiązkiem nałożonym na licencjobiorcę jest zachowanie utworu w oryginalnej postaci (nietworzenie utworów zależnych). Jest to najbardziej restrykcyjna ze wszystkich licencji CC, ze względu na ograniczenie swobody korzystania z utworu w najszerszym zakresie.

Atrybutem występującym we wszystkich wzorcach jest klauzula BY, a atrybuty SA i ND wzajemnie się wykluczają. Licencje bez warunku ND, co do zasady (z wyjątkiem licencji CC0, opisanej w dalszej części artykułu) wymagają przy rozpowszechnianiu utworów zależnych wskazania utworu oryginalnego, a także informacji o wprowadzonych zmianach i autorstwie. Tym samym gwarantują nienaruszalność integralności utworu. Nie wszystkie sześć wzorów uznawane jest za „wolne licencje”. Jedynie licencje CC-BY oraz CC-BY-SA dają użytkownikowi zakres uprawnień wystarczający do takiego określenia. Obie licencje są licencjami niewyłącznymi (uprawniony zawsze zachowuje prawa autorskie, dając jednocześnie możliwość wykorzystywania i modyfikowania treści). Licencja CC-BY daje użytkownikom najwięcej swobody, umożliwiając zarówno komercyjne wykorzystywania, jak i tworzenie utworów zależnych bez żadnych dodatkowych warunków. Jeśli wskazane jest ograniczenie komercyjnego wykorzystania utworów, rozwiązaniem jest zastosowanie licencji CC-BY-SA, która pozwala na komercyjne wykorzystanie, o ile utwory zależne będą nadal dostępne na tej samej licencji. Pozostałe wzorce zakazują albo korzystania komercyjnego, albo korzystania (rozpowszechniania) z opracowań. Jeśli autor nie zgadza się na modyfikację utworu, powinien wziąć pod uwagę licencję z warunkiem ND. Jeśli natomiast 
celem autora ma być udostępnienie jak najszerszej informacji o działalności i dostęp do efektów pracy, to pożądane wydają się najbardziej liberalne licencje (CC-BY lub CC-BY-SA). Wydają się one także najwłaściwsze dla instytucji finansowanych ze środków publicznych, gwarantując wszystkim równy dostęp do materiałów opłaconych z tych środków. Z kolei licencje $\mathrm{z}$ warunkiem NC często stosowane są tam, gdzie organizacji zależy na rozpowszechnianiu swoich treści przy jednoczesnym zachowaniu możliwości zarabiania na nich (zachowane jest wówczas prawo do udzielenia „licencji komercyjnej”)9. Dokładny zakres obowiązków zależy zatem od konkretnego, wybranego wzorca licencji CC. W celu ułatwienia wyboru odpowiedniego wzorca organizacja Creative Commons udostępniła na swojej stronie mechanizm pomagający dopasować do swoich potrzeb pożąane elementy licencji ${ }^{10}$.

Jeżeli uprawniony zdecyduje się udostępnić swój utwór na licencji CC, to w zasadzie nie ma już wpływu na to, kto stanie się licencjobiorcą. Licencje są udzielanie każdemu zainteresowanemu, a przekazanie utworu kolejnemu użytkownikowi czyni z tego użytkownika kolejnego licencjobiorcę. Wycofanie z obrotu utworu, który został rozpowszechniony na podstawie odpowiedniego wzorca, może być bardzo trudne lub nawet niemożliwe (zob. uwagi poniżej). W każdym przypadku licencjodawca powinien podjąć przemyślaną decyzję co do wyboru odpowiedniej licencji. Należy rozważyć, czy do zaakceptowania jest komercyjne wykorzystywanie udostępnianego utworu oraz czy zgadzamy się na rozpowszechnianie opracowań, a jeśli tak, to czy chcemy wymagać od użytkowników, aby utwory zależne były dostępne na tej samej licencji.

Technicznie licencje CC składają się z trzech „warstw”, które mają zapewnić czytelność oznakowania praw i warunków wybranych przez uprawnionego (gwarantują, że licencje są „zrozumiałe” dla twórców, odbiorców czy też wyszukiwarek internetowych ${ }^{11}$. Każda ma postać: „przystępnego podsumowania” (Commons Deed), „licencji właściwej”, czyli tekstu prawnego oraz wzorca oznakowania utworów symbolem, dzięki któremu można automatycznie rozpoznać i wyszukać utwory. Przystępne podsumowanie to „wyciąg” z postanowień licencji wskazujący istotę zakresu uprawnień. Celem jest przedstawienie w przejrzysty sposób uprawnień wynikających z wybranego wzorca. Samo w sobie nie stano-

9 J.Hofmokliin.,Przewodnikpootwartości, CreativeCommons Polska, 2013, s. 34, https:// ngoteka.pl/bitstream/handle/item/180/Przewodnik-po-otwartos\%CC\%81ci_2013. pdf, publikacja dostępna na licencji Creative Commons Uznanie autorstwa 3.0. Polska, https://creativecommons.org/licenses/by/3.0/pl/legalcode [dostęp 19 września 2019 r.].

10 W tym celu należy odpowiedzieć na następujące pytania: czy zezwalasz na udostępnianie adaptacji utworu? czy zezwalasz na komercyjne wykorzystywanie swojego utworu?, https://creativecommons.org/choose/ [dostęp 19 września 2019 r.].

11 Https://creativecommons.org/licenses/ [dostęp 19 września 2019 r.]. 
wi właściwej licencji ani nie wiąże stron, pełni niejako rolę wstępu ${ }^{12}$. „Licencja właściwa” to właściwe postanowienia. Z kolei trzeci element stanowi oznaczenie, które ułatwia komputerom odnalezienie informacji, że dany utwór jest udostępniony na podstawie konkretnego wzorca (podsumowanie warunków licencji wpisane w odpowiedni format).

\section{Generacje licencji CC}

Udostępnianie przez organizację Creative Commons wzorce są aktualizowane. Nowe wersje powstają w celu usuwania błędów i „niedoskonałości”, jakie mogły ujawnić się w trakcie ich stosowania ${ }^{13}$. Jednym z powodów wprowadzenia zmian było także ich dostosowanie do potrzeb sektora publicznego, coraz częściej korzystającego z licencji CC ${ }^{14}$. Ogólne założenia pozostają jednak niezmienione. Mimo wprowadzenia nowych wariantów, wszystkie poprzednie nadal obowiązują.

Dotychczas licencje CC ukazały się w kilku wersjach: 1.0, 2.0, 2.5, 3.0 i 4.0 (ostatnia opublikowana 25 listopada 2013 r.). Przed wersją 4.0 licencje pisane były przede wszystkim pod kątem amerykańskiego prawa autorskiego. W celu dostosowania do innych systemów prawnych powstawały lokalne warianty (np. „Creative Commons - Uznanie autorstwa 3.0 Polska”). Wersje krajowe wzorców z założenia są dostosowane do specyfiki prawa danego kraju. Do licencji $\mathrm{w}$ wersji 2.5 podstawowe warianty nazywano generic, a następnie unported (od wersji 3.0). Wersja 3.0 stworzona została jako zgodna z prawem międzynarodowym (co ma pozwalać na łatwiejsze dostosowanie do przepisów krajowych). Najnowsza wersja 4.0 (international), zakładająca jedynie jej przetłumaczenie, została przygotowana $z$ uwzględnieniem specyfiki różnych systemów prawnych, tak by nie tworzyć wersji krajowych.

Zgodnie z najbardziej aktualną wersją 4.0 licencje obecnie obejmują prawa sui generis do baz danych. Zawierają także postanowienia, zgodnie z którymi licencjodawca zrzeka się ochrony swojego wizerunku w zakresie, w jakim pozwala na to określone prawo. W najnowszej wersji wystarczy także podać informacje o autorze i licencji - nie jest wymagane podawanie tytułu utworu w informacji licencyjnej, jeśli równocześnie podajemy odnośnik do strony, na której wraz z utworem znajduje się jego opis. Istnieje także możliwość nakazania przez licencjodawcę usunięcia informacji o jego autorstwie z określonych kopii utworu lub utworów zależnych w sytuacji, gdy nie chce być związany z określonym użyciem jego utworu (w wersjach 3.0 to uprawnienie dotyczyło jedynie utworów zależnych). Nowe wersje wpro-

J. Hofmokl i in., Przewodnik po otwartości, op. cit., s. 81.

13 E. Delert, Creative Commons (CC), „Themis Polska Nova” 2014, nr 1(6), s. 282.

14 Https://creativecommons.pl/2016/11/licencje-4-0-po-polsku/ [dostęp 19 września 2019 r.]. 
wadzają 30 dni na usunięcie naruszeń licencji. Naruszenie licencji, tak jak wcześniej, oznacza automatyczne wygaśnięcie licencji. Licencja zostaje jednak przywrócona, jeśli w ciągu 30 dni od ustalenia naruszenia zostanie ono naprawione ${ }^{15}$.

W 2009 r. powstała także licencja CC0 (universal) ${ }^{16}$. Jest to rozwiązanie dla twórców, którzy chcą dać jak największą swobodę w rozpowszechnianiu, modyfikowaniu i ponownemu wykorzystywaniu ich utworów. Oznaczając swój utwór znakiem CC0, zrzekają się swoich praw autorskich, pokrewnych i powiązanych $\mathrm{w}$ maksymalnym zakresie dozwolonym przez obowiązujące $\mathrm{w}$ danych kraju prawo ${ }^{17}$. Tym samym licencja ta w bardzo szeroki sposób określa zakres praw, które zostają przekazane do domeny publicznej. Zgodnie z jej treścią licencjodawca zrzeka się wszystkich przysługujących mu praw do utworu w sposób trwały i nieodwołalny, co oznacza, że zrzeka się swoich praw na okres, przez jaki chronione są przez prawo. Rozwiązanie to jest przygotowane dla osób, które nie chcą zachować w zasadzie żadnych uprawnień ani też wymagać przestrzegania jakichkolwiek obowiązków ${ }^{18}$.

\section{Charakter prawny licencji Creative Commons ${ }^{19}$}

Z formalnoprawnego punktu widzenia licencje Creative Commons są umowami upoważniającymi do korzystania z utworu, do których zastosowanie mają zarówno przepisy ustawy z 4 lutego $1994 \mathrm{r}$. o prawie autorskim i prawach pokrewnych $^{20}$, jak i ustawy z 23 kwietnia 1964 r. - Kodeks cywilny ${ }^{21}$. O ich specyfice decyduje natomiast katalog cech nadający im „wolnościowy” charakter.

Każda licencja CC jest nieodpłatna i niewyłączna. Udzielana jest bez ograniczeń czasowych czy też terytorialnych i obejmuje wszystkie znane pola eksploa-

15 Https://creativecommons.pl/tag/licencje-4-0/; szczegółowy opis zmian: https://wiki. creativecommons.org/wiki/4.0; https://creativecommons.org/version4/ [dostęp 19 września 2019 r.].

16 Https://creativecommons.org/publicdomain/zero/1.0/legalcode [dostęp 19 września 2019 r.].

17 Https://creativecommons.pl/2015/04/konsultacje-mechanizmu-creative-commons-zero-cc0/ [dostęp 19 września 2019 r.].

18 K. Siewicz, Analiza prawna „Creative Commons 0”, http://fbc.pionier.net.pl/pro/wp-content/uploads/2012/07/CC0_analiza.pdf, opracowanie dostępne na licencji Creative Commons Uznanie autorstwa 3.0 (CC BY-3.0), https://creativecommons.org/ licenses/by-sa/3.0/ [dostęp 19 września 2019 r.].

19 Przedstawione rozważania, mimo iż w większości dotyczą wszystkich licencji CC, odnoszą się do wersji licencji CC-BY Polska 3.0, https://creativecommons.org/licenses/ by/3.0/pl/legalcode [dostęp 19 września 2019 r.].

20 T.j. Dz.U. 2018, poz. 1191, ze zm.; dalej: prawo autorskie lub pr. aut.

${ }_{21}$ T.j. Dz.U. 2018, poz. 1025, ze zm.; dalej: Kodeks cywilny lub k.c. 
tacji. Wolne licencje pozwalają zatem na bardzo szerokie korzystanie z utworów oraz ich ewentualnych opracowań ${ }^{22}$. Umowa licencji CC jest także umową adhezyjną (przystąpienia, wzorcową ${ }^{23}$ ), tj. nie zakłada negocjacji indywidualnych postanowień umownych.

Niewyłączny charakter licencji CC nie ogranicza możliwości w zakresie eksploatacji utworu i udzielania dalszych licencji. Licencje te są także nieograniczone w przestrzeni i czasie - licencjodawca nie ustanawia barier terytorialnych ani czasowych. Założenie o bezterminowości i brak możliwości wypowiedzenia (tzw. wieczysty charakter licencji CC) wzbudza największe kontrowersje (o czym w dalszej części artykułu). Z założenia wygaśnięcie umowy następuje jedynie w przypadku naruszenia jej postanowień przez korzystającego z utworu i wówczas odbywa się automatycznie bez potrzeby dokonywania przez licencjodawcę jakichkolwiek czynności. Licencja CC udzielana jest także z ograniczeniem odpowiedzialności za szkodę oraz z wyłączeniem rękojmi i gwarancji za wady licencjonowanego utworu ${ }^{24}$. Szerokiemu zakresowi uprawnień licencjobiorcy towarzyszy zatem szerokie wyłączenie odpowiedzialności licencjodawcy.

\section{Charakter licencji Creative Commons a uwarunkowania polskiego prawa cywilnego ${ }^{25}$}

Model udostępniania twórczości na zasadach proponowanych przez organizację Creative Commons - mimo międzynarodowego charakteru - będzie zawsze oceniany pod kątem regulacji konkretnego systemu prawnego. Biorąc pod uwagę opisane wcześniej cechy i charakter licencji CC, warto wskazać pewne wątpliwości, jakie mogą powstać w związku z ich funkcjonowaniem na gruncie polskiego prawa cywilnego. Najczęściej podnoszonym zastrzeżeniem jest bezterminowy charakter licencji CC i brak możliwości ich wypowiedzenia ${ }^{26}$.

Zgodnie z postanowieniami pkt 7a zdanie pierwsze licencji CC-BY 3.0 Polska: Licencja automatycznie wygasa w przypadku jakiegokolwiek jej naruszenia przez

$22 \quad$ K. Siewicz, Otwarty dostęp, op. cit., s. 16.

23 M. Bednarek, Wzorce umów [w:] System prawa prywatnego, t. 5, Prawo zobowiązań część ogólna, red. E. Łętowska, 2013, Legalis.

24 W. Machała, Wybrane cywilnoprawne aspekty, op. cit., s. 423.

25 Podobnie jak w podrozdziale „Charakter prawny licencji Creative Commons” przedstawione rozważania odnoszą się licencji CC-BY Polska 3.0, https://creativecommons. org/licenses/by/3.0/pl/legalcode [dostęp 19 września 2019 r.].

26 Zob. W. Machała, Wybrane cywilnoprawne aspekty, op. cit., s. 423; A. Mazur, Licencje Creative Commons - recepcja w prawie polskim i ich zastosowanie, „Internetowy Przegląd Prawniczy” TBSP UJ 2017, nr 3, s. 87, http://www.tbsp.wpia.uj.edu.pl/documents/4137545/137069082/IPP_2017_3/b22184b1-2763-4c66-97a0-676f8b0c7a24 [dostęp 19 września 2019 r.]. 
Licencjobiorcę. Z kolei pkt 7b licencji CC-BY 3.0 Polska stanowi: Licencja udzielana jest na czas nieoznaczony (do momentu wygaśnięcia praw autorskich). Niezależnie od tego Licencjodawca zachowuje prawo do udostępnienia Utworu na innych warunkach, lub do zaprzestania udostępniania Utworu, z tym jednak zastrzeżeniem, że taka decyzja Licencjodawcy nie będzie stanowiła wypowiedzenia lub innego rozwiązania niniejszej Licencji (lub też innej licencji udzielonej na podstawie niniejszej Licencji), która raz udzielona Licencjobiorcy w pełnym wymiarze obowiazuje dopóki nie nastąpi jej wygaśnięcie zgodnie z postanowieniem poprzedzającym.

Z powyższego wynika, po pierwsze, że według postanowień licencji, wygasa ona automatycznie w sytuacji wystąpienia naruszenia. Dalsza eksploatacja utworu uzasadnia postawienie zarzutu naruszenia prawa autorskiego. Po drugie, licencja została udzielona na czas nieoznaczony. Zgodnie z art. 68 pr. aut. licencję udzieloną na czas nieoznaczony można wypowiedzieć z zachowaniem terminów umownych, a w przypadku ich braku - na rok naprzód na koniec roku kalendarzowego (jeśli umowa nie stanowi inaczej). Co więcej, należy wziąć pod uwagę, że wszystkie bezterminowe stosunki prawne o charakterze ciągłym wynikające z umów zobowiązujących można wypowiedzieć - na co explicite wskazuje art. $365^{1}$ k.c. W konsekwencji, według części komentatorów, umowa licencyjna nie może być obwarowana obowiązkiem stron utrzymywania licencji w sposób trwały, nieograniczony w czasie. Tym samym nie można wyłączyć prawa jej wypowiedzenia i licencje CC na gruncie polskiego systemu prawnego nie mają wieczystego charakteru ${ }^{27}$. Warto wskazać, że wzór licencji CC-BY Polska 3.0 nie zawiera zastrzeżenia o braku możliwości jej wypowiedzenia ani żadnego innego zastrzeżenia modyfikującego normę art. 68 ust. 1 pr. aut. ${ }^{28}$. Treść licencji nie rozstrzyga wprost, czy dopuszczalne jest wypowiedzenie w innych przypadkach brak zatem generalnego zakazu wypowiedzenia.

Wydaje się więc, że licencja CC-BY 3.0 Polska może zostać skutecznie wypowiedziana. Omawiana licencja nie jest sprzeczna $z$ art. 68 pr. aut., co więcej, przepis ten będzie stosowany w przypadku jej wypowiadania. Ponieważ w treści licencji nie wskazano żadnych terminów, w zakresie wypowiedzenia nale-

27 W. Machała, Wybrane cywilnoprawne aspekty, op. cit.; zob. także: K. Grzybczyk, Prawo właściwe dla autorskoprawnej umowy licencyjnej, Warszawa 2010, s. 46. Zgodnie z poglądem tego autora „wieczystość” licencji nie budzi zastrzeżeń, ponieważ może być ona zawsze odwołana na mocy art. 68 ust. 1 pr. aut.

28 Warto odnotować, że w licencjach w wersjach 4.0 wskazano czas obowiązywania licencji w następujący sposób: Niniejsza Licencja Publiczna jest udzielona na czas trwania licencjonowanych Praw Autorskich i Praw Podobnych do Praw Autorskich ( $\$ 6$ licencji Creative Commons Uznanie autorstwa 4.0 Międzynarodowa Licencja Publiczna; https://creativecommons.org/licenses/by/4.0/legalcode.pl [dostęp 19 września 2019 r.]. Wydaje się, że powyższa zmiana nastąpiła pod wpływem krytyki dotyczącej omawianej kwestii. 
ży stosować terminy ustawowe ${ }^{29}$. Takie wypowiedzenie powinno przyjąć formę oświadczenia skierowanego do każdej z osób, które uzyskały utwór udostępniony na tej licencji, ponieważ wszystkie są potencjalnie licencjobiorcami.

W literaturze pojawiają się też głosy wskazujące na art. 68 pr. aut. jako lex specialis wobec regulacji Kodeksu cywilnego, pozwalający na umowne wyłączenie możliwości wypowiedzenia. Zgodnie z powyższym poglądem sformułowanie ,jeżeli umowa nie stanowi inaczej” pozwala stronom na uregulowanie okresu obowiązywania umowy i jej wypowiedzenia inaczej niż przewiduje to przepis, także z wyłączeniem możliwości wypowiedzenia takiej umowy ${ }^{30}$.

Do zagadnienia w zakresie możliwości zawarcia „niewypowiadalnej” umowy licencji niewyłącznej odniósł się także Sąd Apelacyjny w Warszawie, który w wyroku z 17 grudnia 2015 r. uznał, że zawarte między stronami umowy licencyjne miały charakter bezterminowy oraz zawierały wyłączenie możliwości ich umownego wypowiedzenia ${ }^{31}$. Wydaje się zatem, że orzecznictwo dopuszcza możliwość zawarcia umowy licencji niewyłącznej z wyłączeniem możliwości wypowiedzenia, nie wyjaśnia jednak istniejących w tym zakresie wątpliwości.

Abstrahując od powyższego, należy podkreślić, że w praktyce możliwość wypowiedzenia takiej licencji może okazać się iluzoryczna. Wypowiedzenie umowy jest jednostronną czynnością prawną i dla swojej skuteczności wymaga doręczenia drugiej stronie. Ponieważ umowa licencji CC jest zawierana wskutek przystąpienia do eksploatacji, zidentyfikowanie drugiej strony umowy może często okazać się niemożliwe. Jak trafnie podnosi się w doktrynie, doręczenie drugiej stronie

29 K. Siewicz, Prawo autorskie, op. cit., s. 10.

30 T. Targosz, Komentarz do art. 68 [w:] Prawo autorskie i prawa pokrewne. Komentarz, red. F. Damian, 2015, LEX nr 528876. Autor ten wskazuje: $Z$ reguły wyłaczenie możliwości wypowiedzenia umowy nie będzie możliwe w przypadku umowy licencyjnej wyłącznej, może być natomiast dopuszczone w umowach licencji niewyłacznej, których funkcja jest $w$ istocie umożliwienie korzystania $z$ dobra niematerialnego w sposób podobny jak $w$ umowie sprzedaży, gdzie forma licencji musi być zastosowana jedynie $z$ uwagi na ochronę przedmiotu umowy jako dobra własności intelektualnej. Wymagać należy, by umowy te nie rodziły dla stron - poza zobowiązaniem licencjodawcy do umożliwienia korzystania, a zatem innymi słowy do znoszenia korzystania na podstawie umowy - żadnych dodatkowych obowiązków o charakterze ciaglym lub okresowym. Dogmatyczne uzasadnienie tego poglądu wydaje się możliwe dlatego, że art. 68 ust. 1 stanowi mimo wszystko lex specialis $w$ stosunku do art. $365^{1}$ k.c. Skoro więc w przepisie tym ustawodawca wyraźnie zezwala na odmienna regulację problemu wypowiedzenia umowy terminowej, to można argumentować, że uwzględnia właśnie specyfikę utworów prawa autorskiego oraz praw autorskich jako praw na dobrach niematerialnych, w przypadku których wyłaczenie możliwości wypowiedzenia lub jej ograniczenie nie rodzi zawsze takich zagrożeń jak $w$ "klasycznych” stosunkach zobowiązaniowych ze świadczeniem ciagtym znanych prawu cywilnemu.

31 Sygn. akt VI ACa 1735/14, http://orzeczenia.ms.gov.pl/content/\$N/154500000003003_ VI_ACa_001735_2014_Uz_2015-12-17_002 [dostęp 19 września 2019 r.]. 
wypowiedzenia wydaje się praktycznie niewykonalne ${ }^{32}$. Co więcej, jako że licencje te nie są ograniczone terytorialnie, może się okazać, że jeśli nawet wypowiedzenie licencji przez licencjodawcę będzie skuteczne $\mathrm{w}$ określonym systemie prawnym, to w stosunku do licencjobiorców, których prawo to nie dotyczy - licencje CC nie zostaną wypowiedziane. Ponadto zawsze będzie możliwe zawieranie kolejnych licencji za ich pośrednictwem, ponieważ z ich konstrukcji wynika, że są one każdorazowo zawierane z licencjodawcą, który udostępnił swój utwór, nawet jeśli kolejny licencjobiorca uzyskał je od innego licencjobiorcy. Skuteczne wypowiedzenie nie oznacza również, że licencjobiorcy mają całkowity zakaz korzystania z utworu, który podlegał licencjonowaniu. Zachowają oni uprawnienia do korzystania $\mathrm{z}$ tego utworu zgodnie $\mathrm{z}$ dozwolonym użytkiem osobistym. W literaturze przedmiotu podkreśla się, że nie są znane przypadki wypowiadania wolnych licencji33.

Kolejne zastrzeżenie dotyczy warunkowego charakteru licencji CC. Zgodnie $\mathrm{z}$ postanowieniami $₫ 7$ lit. a zezwolenie na korzystanie $\mathrm{z}$ utworu wygasa automatycznie z chwilą, kiedy korzystający naruszy postanowienia umowy licencyjnej. Powyższe, w ocenie części przedstawicieli doktryny, oznacza, że licencja jest udzielana pod warunkiem rozwiązującym, gdzie zdarzeniem powodującym ustanie skutków zawarcia umowy licencyjnej jest naruszenie tej umowy przez jedną ze stron ${ }^{34}$. Kwestia tego, czy naruszenie postanowień umowy może być traktowane jako warunek (czyli zdarzenie przyszłe i niepewne), nie jest jednak jednoznacznie oceniania ${ }^{35}$.

Poruszone wyżej zagadnienia, mimo wywoływanych wątpliwości (ze względu na ramy opracowania ograniczone jedynie do warstwy sygnalizacyjnej), nie wykluczają możliwości korzystania z licencji Creative Commons.

\section{Udzielenie licencji CC $^{36}$}

Możliwość udzielenia licencji CC uwarunkowana jest posiadaniem praw do utworu. W sytuacji, kiedy licencjodawcą jest bezpośrednio twórca, może on po

32 W. Machała, Wybrane cywilnoprawne aspekty, op. cit., s. 423.

33 K. Siewicz, Prawo autorskie, op. cit., s. 10.

34 W. Machała, Wybrane cywilnoprawne aspekty, op. cit., s. 423.

35 Por. np. postanowienia SN z: 10 kwietnia 2003 r., sygn. akt III CKN 1335/00; 24 czerwca 2005 r., sygn. akt V CK 799/04; 26 września 2007 r., sygn. akt IV CSK 118/07; 22 marca 2013 r., sygn. akt III CZP 85/12; W. Machała, Wybrane cywilnoprawne aspekty, op. cit., s. 423; D. Klimas, Licencje „Creative Commons” $3.0 \mathrm{w}$ polskim porzadku prawnym oraz ich byt $w$ wirtualnym świecie - wybrane aspekty prywatnoprawne, „Prawo Mediów Elektronicznych" 2015, nr 1, s. 55.

36 Przedstawione rozważania odnoszą się do postanowień licencji CC-BY Polska 3.0, https://creativecommons.org/licenses/by/3.0/pl/legalcode [dostęp 19 września 2019 r.]. 
prostu udostępnić swój utwór w określony sposób. Udzielenie licencji CC, tak jak każdej innej licencji niewyłącznej, nie wymaga żadnej szczególnej formy. Za wystarczające należy uznać, że uprawniony w sposób wyraźny da do zrozumienia, że utwór jest udostępniony na konkretnej licencji. Ważne jest, aby wskazać, o jaką licencję chodzi. W literaturze przedmiotu podkreśla się, że licencje CC tworzą bezpośrednią relację między uprawnionym a poszczególnymi użytkownikami. Istotne dla stworzenia tej relacji jest wyraźne zakomunikowanie woli twórcy do objęcia utworu postanowieniami konkretnego wzorca. Udzielenie licencji polega zatem na opublikowaniu utworu wyraźnie oznaczonego odwołaniem do konkretnego wzorca ${ }^{37}$. Błędny opis może utrudnić lub uniemożliwić korzystanie z utworu zgodnie z licencją. Poprawne oznakowanie materiałów objętych licencją powinno być widoczne i zrozumiałe dla odbiorców (jak i wyszukiwarek internetowych, które ułatwiają ich odnalezienie). Przykładowe sposoby prezentowane są na stronach organizacji Creative Commons (w zależności od nośnika i formatu multimediów). Mimo braku jednego, powszechnie obowiązującego systemu, należy zawsze podać informację o autorze lub autorach albo o innym niż autor licencjodawcy, źródło (opis bibliograficzny utworu lub link, jeśli wykorzystywany utwór jest dostępny w sieci), nazwę licencji z odnośnikiem do strony licencji w serwisie Creative Commons lub - w przypadku druku - adresem URL do niej.

Licencji na korzystanie z utworu może udzielić także posiadacz majątkowych praw autorskich niebędący twórcą. Przy ocenie możliwości udostępniania utworu przez uprawnionego niebędącego twórcą podstawowe znaczenie ma ustalenie, jaki zakres praw przysługuje temu podmiotowi. Zgodnie bowiem z zasadą nemo plus iuris ad alium transferre potest quam ipse habet licencjodawca, aby skutecznie ustanowić licencję, powinien być sam do tego uprawniony. W polskim systemie prawa autorskiego, bazującym na założeniu, że eksploatacja utworu jest co do zasady wyłącznym uprawnieniem twórcy, osoba trzecia może uzyskać uprawnienie do korzystania $\mathrm{z}$ utworu w drodze dziedziczenia bądź na podstawie umowy (art. 41 ust. 1 pkt 1 pr. aut.) ${ }^{38}$. Umowy dotyczące autorskich praw majątkowych mogą przyjąć postać umowy o przeniesienie praw autorskich lub umowy o korzystanie z utworu, tzw. licencji. Umowy te różnią się swoim charakterem i skutkami, jakie z tego wynikają. Celem umowy przenoszącej prawa autorskie jest zmiana uprawnianego $\mathrm{z}$ tytułu praw autorskich ${ }^{39}$. Ma ona charakter rozporządzający. Brak jest natomiast jednomyślności odnośnie do charakteru umowy

37 K. Siewicz, Prawo autorskie, op. cit., s. 9.

38 Zob. J. Barta, R. Markiewicz, Obowiązek wymienienia pól eksploatacji w umowie licencyjnej, „Zeszyty Naukowe Uniwersytetu Jagiellońskiego” 2007, nr 4, s. 23. Zgodnie z zaprezentowaną koncepcją można również udzielić zezwolenia na korzystanie $\mathrm{z}$ utworu jednostronną czynnością prawną, tzn. w drodze oświadczenia woli złożonego przez twórcę.

39 T. Targosz [w:] Umowy przenoszace autorskie prawa majątkowe, red. T. Targosz, K. Włodarska-Dziurzyńska, Warszawa 2010, s. 18. 
licencyjnej. Prawo autorskie nie rozstrzyga tej kwestii, a w doktrynie zarysowały się różne stanowiska nadające umowie licencyjnej charakter zobowiązujący, zobowiązująco-upoważniający albo rozporządzający. Poglądem dominującym jest uznanie umowy licencyjnej za umowę o charakterze zobowiązaniowym ${ }^{40}$. Niezależnie od kwalifikacji umowy licencyjnej nie rodzi ona skutków rzeczowych, a jedynie obligacyjne. W ramach licencji podmiot autorskich praw majątkowych udziela innej osobie zezwolenia na korzystanie z jego utworu w sposób wyłączny lub niewyłączny. W przypadku licencji wyłącznej licencjobiorca jest jedynym podmiotem upoważnionym do korzystania z utworu (jednocześnie podmiot praw autorskich zobowiązuje się do nieudzielania licencji innym i niekorzystania z utworu samemu). Licencja niewyłączna nie ogranicza możliwości podmiotu praw autorskich w zakresie eksploatacji utworu i udzielania dalszych licencji. Umowa o przeniesienie autorskich praw majątkowych i umowa licencji wyłącznej wymagają pod rygorem nieważności złożenia oświadczeń przez obie strony w formie pisemnej.

Przygotowując odpowiednią umowę (zarówno w przypadku umowy o przeniesienie autorskich praw majątkowych, jak i umowy o korzystanie $\mathrm{z}$ utworu) z twórcą, w pierwszej kolejności należy dokładnie określić, na jakich polach eksploatacji przeniesiono prawa majątkowe oraz jakie są uprawnienia w zakresie praw zależnych. Innymi słowy, umowa powinna zawierać szczegółowo i jak najszerzej wymienione pola eksploatacji oraz odpowiednie postanowienia dotyczące utworów zależnych. Zgodnie z art. 41 ust. 2 pr. aut. konieczne jest określenie zakresu - odpowiednio - przeniesienia praw i zezwolenia na korzystanie przez wymienienie pól eksploatacji objętych przeniesieniem lub zezwoleniem. Tym samym ważne jest, by przeniesienie praw autorskich nastąpiło na tych samych polach eksploatacji, które objęte są licencją CC - zakres pól eksploatacji powinien być tożsamy (w praktyce zakres umowy z twórcą mógłby mieć szerszy zakres pól eksploatacji, ale wydaje się, że licencje Creative Commons wymieniają wszystkie

40 W stanowisku uznającym zobowiązująco-upoważniający albo upoważniający charakter umowy licencyjnej wskazuje się na istnienie pewnego rodzaju upoważnienia do korzystania $\mathrm{z}$ utworu oraz ewentualnie zobowiązania. Z kolei zgodnie z poglądem o rozporządzającym charakterze podnosi się, że licencja nadal jest uprawnieniem względnym (a zatem skutecznym wobec licencjodawcy), jednak równocześnie ma stanowić obciążenie prawa bezwzględnego. Pogląd ten: przyjmuje M. Kępiński, który uznaje, że jej „bezpośrednim skutkiem jest obcią̇enie praw wyłacznych. Obciążenie takie polega na uchyleniu możliwości występowania z roszczeniami z tytułu naruszenia praw wyłącznych $w$ stosunku do licencjobiorcy na czas trwania umowy [...] Skutkiem umowy licencyjnej jest nabycie przez licencjobiorce własnych praw. Prawa te moga być albo skuteczne tylko względem licencjodawcy lub jego następców prawnych, albo także względem osób trzecich", J. Barta, R. Markiewicz, Prawo autorskie, Warszawa 2016, s. 327. 
znane pola eksploatacji). Zgodnie z postanowieniami zawartymi w pkt 3 licencji CC-BY 3.0 Polska pola eksploatacji określone są następująco:

- zwielokrotnianie utworu, włączanie utworu do jednego lub więcej zbiorów, zwielokrotnianie utworu włączonego do zbiorów (lit. a),

- rozpowszechnianie oraz publiczne wykonanie utworu, w tym utworu włączonego do zbiorów (lit. c),

- pobieranie danych z utworu oraz ich wtórne wykorzystanie (lit. e).

Przy czym „zwielokrotnianie” oznacza wytwarzanie jakąkolwiek techniką egzemplarzy utworu w tym: drukarską, reprograficzną, zapisu magnetycznego oraz cyfrową (pkt 1 lit. i). Z kolei „rozpowszechnianie” odnosi się do wprowadzania do obrotu, użyczenia lub najmu oryginału albo egzemplarzy utworu lub utworu zależnego (pkt 1 lit. c). Natomiast „publiczne wykonanie” oznacza publiczne wykonanie, wystawienie, wyświetlenie, odtworzenie oraz nadawanie i reemitowanie, a także publiczne udostępnianie utworu w taki sposób, aby każdy mógł mieć do niego dostęp w miejscu i w czasie przez siebie wybranym (pkt 1 lit. h).

Ponadto umowa o przeniesienie praw autorskich (nawet dotycząca wszystkich znanych pól eksploatacji) nie przenosi automatycznie na nabywcę prawa do wykonywania praw zależnych do utworu. Zgodnie z art. 46 pr. aut., jeżeli umowa nie stanowi inaczej, twórca zachowuje wyłączne prawo zezwalania na wykonywanie zależnego prawa autorskiego, mimo że w umowie postanowiono o przeniesieniu całości praw majątkowych. Przeniesienie całości autorskich praw majątkowych do utworu - bez regulacji umownych dotyczących prawa zależnego do tego utworu - uniemożliwia rozporządzanie (korzystanie) z opracowań tego utworu. Abstrahując od charakteru praw zależnych, należy podkreślić dystynktywność uprawnień powiązanych z utworem zależnym wynikającą z art. 2 oraz art. 46 pr. aut. W odniesieniu do utworów zależnych licencja CC-BY Polska 3.0 wskazuje na możliwość „sporządzania i zwielokrotniania” - pod warunkiem, że: wszelkie takie Utwory Zależne, w tym wszelkie tłumaczenia na jakimkolwiek nośniku zostały $w$ rozsądnym zakresie wyraźnie oznaczone, wyróżnione lub $w$ inny sposób zostało na nich wskazane, że w oryginalnym Utworze dokonano zmian (lit. b) oraz „rozpowszechniania oraz publicznego wykonania” (lit. d). Licencja pozwala zatem na tworzenie i swobodne rozpowszechnianie opracowań. W umowie należy zatem zadbać o odpowiednie postanowienia w zakresie praw zależnych.

Ponadto, aby uniknąć wątpliwości dotyczących możliwości udostępniania utworu na licencji CC, umowa powinna uwzględniać:

- zgodę na udostępnienie utworu na otwartych licencjach, np. Wykonawca rozumie i akceptuje fakt, że Zamawiajacy będzie udostępniał dzieło na podstawie wolnych licencji Creative Commons Uznanie Autorstwa 3.0 Polska w brzmieniu dostępnym na stronie http://creativecommons. org/licenses/by-sa/3.0/pl/ czy też: 
W celu uniknięcia wszelkich wątpliwości, Strony oświadczają, że ich zgodnym zamiarem jest przeniesienie na Zamawiającego uprawnień $w$ zakresie umożliwiającym udostępnianie utworu w oparciu o licencję Creative Commons Uznanie Autorstwa 3.0 Polska albo kolejna wersje tej licencji. Pelny tekst licencji Creative Commons Uznanie Autorstwa 3.0 Polska stanowi załacznik do Umowy.

- oznaczenie, w jaki sposób utwór będzie udostępniany,

np. W celu poprawnego informowania osób, którym utwory będa udostępniane o udzielonych im licencjach, Zamawiający umieści następująca informację wraz $z$ utworem, w sposób umożliwiający odbiorcom zapoznanie się z nią: Zezwala się na korzystanie z [tytuł Utworu] (dalej: Utwór) na warunkach licencji [np. Creative Commons Uznanie autorstwa Polska 3.0 (znanej również jako CC-BY), dostępnej pod adresem https://creativecommons.org/licenses/by/3.0/pl/legalcode lub innej wersji językowej tej licencji lub którejkolwiek późniejszej wersji tej licencji, opublikowanej przez organizację Creative Commons.

Odpowiednia umowa może regulować kwestie związane z licencjami CC na wiele innych sposobów, a konkretne rozwiązania zależą od indywidualnych potrzeb $^{41}$.

\section{Podsumowanie}

Zaproponowany przez organizację Creative Commons model jest postrzegany jako alternatywa - a czasem i zagrożenie - dla tradycyjnego obrotu prawami autorskimi i pokrewnymi. Pomimo upływu siedemnastu lat od pojawienia się pierwszej wersji licencji CC i stale rosnącej ich popularności, proponowane rozwiązania nadal wzbudzają kontrowersje, a tematyka ta pozostaje poza zainteresowaniem ustawodawcy. Stosowanie mechanizmów i instytucji wynikających z prawa cywilnego wydaje się niewystarczające, może także rodzić niebezpieczeństwo wystąpienia wątpliwości w zakresie odpowiedniego ich stosowania. Stały wzrost liczby utworów udostępnianych na licencjach CC potwierdza z kolei potrzebę funkcjonowania i akceptację proponowanych rozwiązań. W celu zapewnienia pewności obrotu, a także poszanowania woli uprawnionych, którzy decydują się na udostępnianie utworów na wolnych licencjach, zasadne wydaje się stworzenie odpowiednich rozwiązań legislacyjnych, które w sposób kompleksowy uregulowały omawianą tematykę i umożliwiałyby korzystanie w pełni z licencji Creative Commons.

${ }^{41}$ Przykładowe wzorce umów znajdują się na stronach Koalicji Otwartej Edukacji: http://koed.org.pl/pl/wzory-umow/ [dostęp 19 września 2019 r.]. 


\section{Bibliografia}

Barta J., Markiewicz R., Obowiązek wymienienia pól eksploatacji w umowie licencyjnej, „Zeszyty Naukowe Uniwersytetu Jagiellońskiego” 2007, nr 4.

Barta J., Markiewicz R., Prawo autorskie, Warszawa 2016.

Bednarek M., Wzorce umów [w:] System prawa prywatnego, t. 5, Prawo zobowiązań część ogólna, red. E. Łętowska, 2013, Legalis.

Grzybczyk K., Prawo właściwe dla autorskoprawnej umowy licencyjnej, Warszawa 2010.

Hofmokl J. i in., Przewodnik po otwartej nauce, 2009, https://otwartanauka.pl/images/ PDFs/przewodnik-po-otwartej-nauce.pdf.

Hofmokl J. i in., Przewodnik po otwartości, Creative Commons Polska, 2013.

Klimas D., Licencje „Creative Commons” 3.0 w polskim porządku prawnym oraz ich byt $w$ wirtualnym świecie - wybrane aspekty prywatnoprawne, „Prawo Mediów Elektronicznych" 2015, nr 1.

Klimas D., Zwolińska A., Sporządzanie umów elektronicznych. Komentarz praktyczny, wzory umów, orzecznictwo, red. J. Gołaczyński, 2017, Legalis.

Machała W., Wybrane cywilnoprawne aspekty licencji „creative commons”, „Monitor Prawniczy” 2009, nr 8.

Mazur A., Licencje Creative Commons - recepcja w prawie polskim i ich zastosowanie, „Internetowy Przegląd Prawniczy” TBSP UJ 2017.

Siewicz K., Analiza prawna „Creative Commons 0”, http://fbc.pionier.net.pl/pro/wp-content/uploads/2012/07/CC0_analiza.pdf.

Siewicz K., Otwarty dostęp do publikacji naukowych. Kwestie prawne, 2012, http://otworzksiazke.pl/ksiazka/otwarty_dostep/.

Siewicz K., Prawo autorskie i wolne licencje, Koalicja Otwartej Edukacji, 2010, http://koed. org.pl/wp-content/uploads/2014/09/siewicz-prawo-autorskie-i-wolne-licencje.pdf.

Targosz T., Komentarz do art. 68 [w:] Prawo autorskie i prawa pokrewne. Komentarz, red. F. Damian, 2015, LEX.

Targosz T. [w:] Umowy przenoszące autorskie prawa majątkowe, red. T. Targosz, K. Włodarska-Dziurzyńska, Warszawa 2010. 